This item was submitted to Loughborough's Research Repository by the author.

Items in Figshare are protected by copyright, with all rights reserved, unless otherwise indicated.

\title{
The impact of comparative affective states on online brand perceptions: a five-country study
}

PLEASE CITE THE PUBLISHED VERSION

http://dx.doi.org/10.1108/IMR-10-2013-0237

\section{PUBLISHER}

(C) Emerald

\section{VERSION}

AM (Accepted Manuscript)

\section{PUBLISHER STATEMENT}

This work is made available according to the conditions of the Creative Commons Attribution-NonCommercialNoDerivatives 4.0 International (CC BY-NC-ND 4.0) licence. Full details of this licence are available at: https://creativecommons.org/licenses/by-nc-nd/4.0/

\section{LICENCE}

CC BY-NC-ND 4.0

\section{REPOSITORY RECORD}

Siamagka, Nikoletta Theofania, George Christodoulides, and Nina Michaelidou. 2019. "The Impact of Comparative Affective States on Online Brand Perceptions: A Five-country Study". figshare. https://hdl.handle.net/2134/17137. 


\title{
The Impact of Comparative Affective States on Online Brand Perceptions:
}

\section{A Five-Country Study}

\author{
Dr Nikoletta-Theofania Siamagka, Kings College London (UK) \\ Prof George Christodoulides*, Birkbeck, University of London (UK) \\ Dr Nina Michaelidou, Loughborough University (UK)
}

\section{Structured Abstract:}

Purpose: The extant literature highlights the significant role of brand perceptions in buying behavior and brand equity. Despite the importance of brand perceptions and the proliferation of online brands, research in an online context is still scarce. This study addresses this gap by investigating the effect of positive and negative comparative affective states (online vs. offline) on online brand perceptions. Consistent with existing evidence, highlighting the role of culture on brand perceptions and affective states, this research is conducted in a crossnational setting to identify the stability of the hypothesized relationships among countries.

Design/Methodology/Approach: The study uses consumer survey data from five countries (UK, USA, Australia, Canada and China). After imposing metric and factor variance invariance, we used multi-group CFA to test the hypotheses regarding the impact of positive and negative comparative affective states on online brand perceptions across the five countries in the sample.

Findings: The results show that positive comparative affective states have a significant and positive impact on online brand perceptions across the countries studied, although the impact size varies by country. The findings also show that negative comparative affective states, 
which are context specific and not induced by any particular brand, have no effect on online brand perceptions across the country samples.

Practical Implications: Managers can use the findings reported in this research to inform their branding strategies. For instance, managers may focus on triggering feelings of comfort online as these lead to more favorable online brand perceptions rather than on supressing feelings of caution, as the latter do not directly impact online brand perceptions.

Originality: The study builds on and extends the recent work of Christodoulides et al. (2013) by focusing on online brand perceptions and looking into the role of affective states in a cross-national setting.

Keywords: Affective states, Online brand perceptions, Cross-national, Internet users 


\section{The Impact of Comparative Affective States on Online Brand Perceptions:}

\section{A Five Country Study}

\section{INTRODUCTION}

The fact that brand perceptions strongly influence buying behavior is well documented in the marketing literature (e.g., Low and Lamb, 2000). Brand perceptions are defined as attributes in consumers' memory that are linked to the brand name (Keller, 1993: Romaniuk and Nicholls, 2006). For several years brand perceptions have been the subject of scholarly research, particularly since the seminal article of Gardner and Levy (1955), who highlighted the value of a brand over and above the sum of the functional qualities it offers. Brand perceptions are considered to be a key element of brand equity (Aaker, 1991; 1996) and as such developing, changing or reinforcing brand perceptions is of great interest to marketing researchers; for these perceptions and associations can influence the consumer's response to subsequent marketing activities (Keller, 2003).

Consumers' perceptions towards online brands remain comparatively under-researched despite the proliferation of brands in the digital space and the challenges faced by firms in translating their brand values in computer-mediated environments (Christodoulides, 2009). Understanding the drivers of brand perceptions towards online brands would allow firms to inter alia inform their targeting strategies and resource allocation decisions with regards to considering online/offline channels. The literature has, hitherto, examined few drivers of online brand perceptions (often captured by proxy of brand equity, image or associations) including isolated feelings and emotions (both positive and negative), such as enjoyment and insecurity (e.g., Barnes et al., 2007; Korgaonkar and Wolin, 1999). However, no research to date has collectively examined positive and negative affective states as antecedents of online brand perceptions. 
Affective states may be drivers of online brand perceptions because (1) all channels/media are potentially emotive (Jones et al. 2008) and not always in a positive manner; (2) research on isolated affective states (such as on insecurity or trust) shows that they are capable of affecting attitudes as well as behavior towards online brands (e.g., Lim et al., 2008); and (3) recent research on affective states suggests that various segments of internet users exist based on their affective states and that those discriminate on the basis of their perceptions towards online brands (Christodoulides et al., 2013). For example, one of the segments concerned, 'offline affectivists' are likely to hold negative perceptions towards online brands whilst 'online affectivists’ are more likely to have positive online brand perceptions.

However, research on this subject remains extremely scarce. Consequently, research is needed to determine the role that holistic affective states may play in driving online brand perceptions because managers need to know how best to manipulate perceptions towards online brands. Furthermore, the role that affective states may have in terms of driving online brand perceptions could be affected by county specific features, such as cultural variables like individualism and power distance. For example, cultures low in power distance are likely to hold more positive perceptions towards online brands due to the democratic nature of the Internet (Matusitz and Musambira, 2013) and the collaborative raison d'etre of online brands many of which capitalize on the notion of co-creation (Christodoulides et al., 2012). The success of strategies to enhance online band perceptions by manipulating affective states are likely to be culture specific - managers in some countries may need to use strategies less influenced by culture. Likewise, managers in certain cultures may be better off enhancing the physical dimensions of their brands where their prospective customers are more likely to experience positive affective states offline rather than online.

Accordingly, the current study seeks to identify how online brand perceptions might be shaped by comparative affective states (affective states experienced online versus offline), 
and explores the role of culture on the relationship between online affective states and online band perceptions.

The paper opens with a review of the literature on online brand perceptions, affective states and culture. The methodology, analysis and findings then follow. The paper ends with a discussion of the findings and a concluding section, which highlights significant theoretical and practical implications as well as future research.

\section{CONCEPTUAL BACKGROUND}

Brand Perceptions

Existing literature in brand marketing remains conflicting with regards to defining and measuring consumer perceptions of brands. Current conceptualizations of brand perceptions pertain to the work of Keller (1993) and Aaker (1991; 1996), who address brand perceptions as "psychological representations of brands" (Low and Lamb, 2000, p351) involving essentially attributes in consumer memory or brand associations (Keller, 1993; Romaniuk and Nicholls, 2006). According to Aaker (1991), brand associations constitute a category of the brand's assets and liabilities and include all memory representations linked to the brand (Low and Lamb, 2000). In a similar line, Keller (1993) defines brand associations as "informational nodes linked to the brand node in memory that contain a meaning of the brand for consumers" (p3). These can be construed at different levels of abstraction and generality and are said to underpin consumers’ preferences of brands (Romaniuk and Nenycz-Thiel, 2013), leading to varied marketing outcomes including positive attitudes and brand choice (Keller 1993). They can also vary in valence, strength, coherence and uniqueness (Keller, 1993; Schmitt, 2012). In particular, associations can be created at the level of a brand, but also at a general level (Schmitt, 2012). Additionally, associations can pertain to brand attributes (e.g., 
price, usage imagery etc.), benefits involving functional (e.g. fulfilment of psychological needs), experiential (experience related to the usage of product and/or its attributes) and symbolic benefits (e.g. fulfilment of social needs), as well as brand attitudes, which capture the overall evaluation of a brand (Dobni and Zinkhan, 1990; Keller, 1993; Kwon and Lennon, 2009); however, consumers may create their own associations, in addition to those provided by firms, based on their own motives or cognitions (Keller, 1993; Schmitt, 2012).

\section{Online Brand Perceptions}

Scholarly research remains largely silent about online brand perceptions. However, how consumers' perceive online brands, such as Amazon, Google and eBay, has largely contributed to the success of those brands on a global scale. Given that research on online brand perceptions is scarce, we draw on existing theory on brand perceptions to conceptualize this construct. Hence, in line with the aforementioned literature (Keller, 1993; Keller, 1998; Low and Lamb, 2000), we conceptualize online brand perceptions as referring to associations held about the attributes of online brands. We argue that online brand perceptions vary from offline brand perceptions as the context in which a brand is presented (i.e. online or offline) impacts the level of abstraction of the association, (e.g. product attribute vs. benefits), strength of association (an association regarding an attribute is stronger online compared to offline) and uniqueness (unique to the context) (Degeratu et al., 2000). In support of this argument, Danaher et al. (2003) suggest that brand perceptions linked to offline brands are different from those held about online brands due to the disparity in the type and the level of experience a consumer has with the brand. In particular, in online environments, the brand name plays a pivotal role in consumer behavior since it is seen as encompassing a set information consumers derive to form a choice (Danaher et al., 2003). It is, therefore, argued 
that in online environments perceptions involving the brand [name] may be more important (Degeratu et al., 2000) and that consumers may use the brand name to derive perceptions or associations about product attributes and benefits (Alba et al., 1997; Danaher et al., 2003).

\section{Affective States}

The notion of affect is inconsistently used in the literature to denote feelings, emotions and moods (Bagozzi et al., 1999) or all three (Pieters and Van Raaij, 1988). Ajzen (2001) refers to emotions and moods as affect, while Cohen and Areni (1991) conceptualize affect as feeling states that also comprise emotions and moods. However, moods are generally distinct from emotions, which are defined as mental states of readiness deriving from thoughts and are directed towards situations or objects (Bagozzi et al., 1999; Frijda, 1993; Scherer, 2005). Moods on the other hand, are generally unfocused and low in intensity, which although last longer they lack intentional capacity, hence not leading to action tendencies (Bagozzi et al., 1999; Beedie et al., 2005; Clark and Isen, 1982; Frijda, 1993). As a result, moods are more difficult to verbalize and be attributed to specific causes compared to emotions (Alversia et al., 2013; Cohen and Andrade, 2004).

Given this lack of a universally accepted definition of affect, previous research mostly uses emotions and/or feelings as a proxy measure of affect (e.g., Lavine et al., 1999). Affect consists of both positive and negative feelings and emotions (Laros and Steenkamp, 2005), with research addressing both of them in consumption settings (e.g., Richins, 1997). Researchers have investigated different affective states in relation to consumer behavior and attitudes (Bagozzi et al., 1999; Foxall 1997; Kwortnik and Ross, 2007; Vanhamme and Lindgreen, 2001), positive word of mouth intentions (White, 2010) and viral marketing effectiveness (Dobele et al., 2007). Bagozzi et al. (1999) provide a comprehensive account 
of the impact of emotions on consumer responses and reach the conclusion that 'emotions are ubiquitous throughout marketing' (p.202). Further, numerous studies illustrate the impact of affective states on attitudes towards the ad (Batra and Ray, 1986), customer satisfaction and retention (Mano and Oliver 1993; Westbrook 1987; Westbrook and Oliver, 1991), consumer mistrust of firms (Vanhamme and Lindgreen, 2001), consumers' approach/ avoidance behaviors (Penz and Hogg, 2011) and browsing and shopping behavior (Menon and Kahn, 2002).

Moreover, research indicates that the impact of emotions (and affective states) cannot be generalized across different consumption settings and shopping channels (Christodoulides et al., 2013; Kwortnik and Ross, 2007; Richins, 1997). Research suggests that within different consumption settings consumers experience mixed emotions (Ruth et al., 2002; Williams and Aaker, 2002). Similarly, Kwortnik and Ross (2007) argue that emotions are context-specific and that consumers experience a wide array of emotions across different consumption settings. Hence, consumers may experience positive emotions, such as pleasure, or negative emotions such as anger in some specific consumption situations but these emotions may become less significant in different consumption settings (Celsi et al., 1993; Kwortnik and Ross, 2007).

Researchers have also examined the role of positive and negative affective states within the Internet retail channel (e.g., Jones et al., 2008; Menon and Kahn, 2002; Petz and Hogg, 2011). Jones et al. (2008) suggest that triggering positive emotions online could benefit a brand through increased loyalty, trust and ultimately market share. In a similar line, Menon and Kahn (2002), Petz and Hogg (2011), Lim et al. (2008) suggest that the experience of affective states online (both positive and negative) has a significant impact on online consumer behavior. For example, pleasure experienced during shopping online will subsequently lead to positive perceptions and attitudes (Petz and Hogg, 2011). At the same 
time, consumer experience of negative affective states (e.g., displeasure) in online environments will lead to negative behavior, including, for example, less willingness to browse or desire to linger longer (Menon and Kahn, 2002; Petz and Hogg, 2011). Additionally, Christodoulides et al. (2013) posit that consumers who experience positive affective states online (relative to positive affective states offline) have the strongest positive perceptions of online brands. It is argued that these consumers feel more confident and comfortable online as opposed to offline which explain their positive perceptions towards online brands (Christodoulides et al., 2013). Overall, these findings highlight the key role of affective states in shaping consumer behavior and affecting consumers' perceptions of online brands. Hence, it is hypothesized that:

H1: Positive online affective states will have a positive impact on online brand perceptions.

H2: Negative online affective states will have a negative impact on online brand perceptions.

Online Brand Perceptions, Affective States and Culture

Culture is widely researched as a determinant of consumer behavior (e.g., Erdem et al., 2006; Moon et al., 2008). The relevance of culture in marketing and in particular consumer behavior is manifested in numerous studies, suggesting that cultural factors have become the central focus in consumer research (Shavitt et al., 2008). However, despite the consensus that exists regarding the importance of culture in human or consumer behavior, the conceptual boundaries are less clear. Definitions of culture vary across studies, leading to a significant conceptualization and operationalization problem, where dimensions are loosely defined and 
generally misused (de Mooij, 2013). For instance, the most widely used framework in crosscultural studies, Hofstede’s (1980) cultural dimensions, involves a high degree of ambiguity.

This ambiguity is the result of the identified dimensions being multifaceted (e.g. individualism/collectivism), making them unreal and unable to have a real relationship with anything (Cadogan et al., 2013). In support of the multidimensional nature of individualism/collectivism, Ho and Chiu (1994) suggest that this dimension consists of five distinct factors, including values, responsibility, achievement, autonomy/conformity and selfreliance/interdependence. This, however, does not disregard cultural models but caution should be exercised in order to i) clearly define the level the research focuses on (e.g., culture, nation, group), ii) identify the appropriate framework and its purpose and design (de Mooij, 2013) and finally iii) appreciate the multifaceted nature of dimensions and their distinct impact on human or consumer behavior.

Despite the blurry conceptual boundaries and inconsistencies in existing literature, culture remains an area of interest for marketing scholars. Empirical research highlights the effect of culture on the consumption of products and services across culturally-different countries (Barnes et al., 2007; de Mooij and Hofstede, 2002; Jones et al., 2008; Lim et al., 2008). In particular, researchers find that cultural dimensions (e.g. power distance and collectivism) play an important role in different marketing areas (see Albers-Miller and Gelb, 1996; Soares et al., 2007; Steenkamp et al., 1999; Yaveroglu and Donthu, 2002; Yeniyurt and Townsend, 2003; van Everdingen and Waarts, 2003), including consumers' perceptions and preference towards brands (Erdem et al., 2006; Robinson, 1996; Henseler et al., 2010) as well as purchase intentions towards online brands (e.g., Moon et al., 2008). In a similar line, previous research shows cultural variations with regards to emotions (Matsumoto, 1989; 2006) and affect online (e.g. Christodoulides et al., 2013). Specifically, Christodoulides et al. (2013) 
report variations of affective states based on national culture with Asian countries exhibiting higher levels of affect (e.g. China) in online environments compared to Western countries (US, UK). Despite some evidence to suggest cultural differences may exist, in the absence of strong rationale to pinpoint how culture affects the relationships in the proposed model, we employ a multi-country sample to assess the stability of H1 and H2 across countries.

\section{Control variables}

Demographic variables are also found to influence Internet usage and buying (Park and Jun, 2003). For example, Teo (2001) highlights that gender plays an important role in Internet usage, particularly for downloading and purchasing online. Previous research addressing attitudinal and behavioral outcomes of online consumer behavior uses consumer demographics (e.g., age and gender) and other variables (e.g., Internet buying experience) as control variables (Park and Jun, 2003; Ranaweera et al., 2008). Therefore, consistent with previous research, this study uses age and gender as control variables of online brand perceptions. Figure 1 provides our research model. 


\section{Figure 1: Research Model}

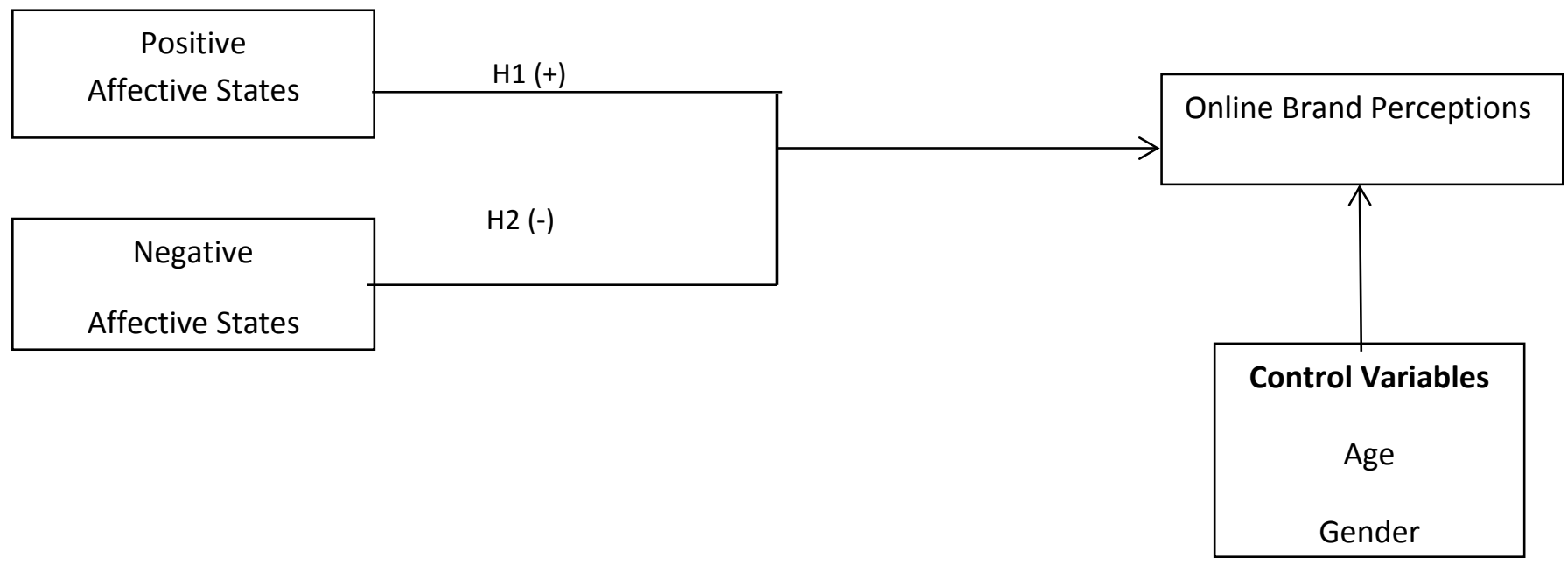

\section{METHODOLOGY}

Survey data was collected in five countries, four Western (UK, USA, Canada and Australia) and one Eastern (China), by a large market research company. Panel data sets and quota sampling were utilized to control for respondent selection bias. Quotas were imposed for gender, age, location (urban/rural) and working status (working/not working) to ensure that the sample from each country was representative of that country's Internet population at the time of the data collection. All respondents were Internet users and members of online research panels. The questionnaire was back-translated and pre-tested by the agency in each country. A completion incentive was offered in the form of a prize draw for a gift voucher worth $\$ 200$, in each country.

\section{Measures}

The nineteen comparative affective states previously identified in the literature (Christodoulides et al., 2013) were incorporated into the questionnaire. Consistent with prior literature, affective states were expected to be two-dimensional (e.g., Tellegen et al., 1999; 
Watson et al., 1988; Watson and Tellegen, 1985), capturing both positive and negative affect. In order to produce composite affective states (negative and positive) as well as examine the relationship between the two affect dimensions and online brand perceptions, a wellestablished scale development procedure was followed (Churchill, 1979) and is detailed in the relevant section of the results. Additionally, online brand perceptions represent consumers' associations regarding online brands in general. Consistent with the branding literature (Christodoulides et al., 2006; Keller, 2003), online brand perceptions were measured through four items, such as "Online brands help me develop my identity and personality” and "Online brands are useful as they allow me to communicate with others" on a 7-point Likert scale. Although online brand perceptions were measured at a general level, a few examples of purely online brands (e.g., Google, eBay) were provided in order to enhance clarity and assist respondents in their answers. Finally, two demographic variables, age and gender, were examined as control variables, in line with extant research that highlights the impact of demographic variables on online consumer behavior. The measures of the items are presented in the Appendix.

\section{RESULTS}

\section{Sample Profile}

Data was collected from 1008 Internet users in the five countries selected. Table 1 summarizes the main demographic characteristics of the sample.

Table 1 here. 


\section{Comparative Affective States Scale}

EFA was first performed on the UK data and after the elimination of items with significant cross loadings, results confirmed the two-factor structure. The first factor, named comfort, captures positive affective states and consists of 7 items while the second factor, named caution, captures negative affective states and consists of 2 items (Figure 2). Following this, the data was subjected to confirmatory factor analysis using AMOS 19 and satisfactory fit indices were obtained in line with Hu and Bentler (1999): $\chi^{2}(26)=65.095(p<.001)$, CFI= $.94, \mathrm{TLI}=.92, \mathrm{RMSEA}=.07$ (Figure 2). Internal consistency reliabilities were satisfactory: $\alpha=$ 0.88 for comfort and $\alpha=0.70$ for caution. Composite reliabilities were also satisfactory (Bagozzi and Yi, 1988): 0.88 for comfort and 0.68 for caution. Using Fornell and Larcker's (1981) criteria, convergent validity and discriminant validities were also established. In particular, AVEs were above recommended levels (Fornell and Larcker, 1981): 0.51 for comfort and 0.52 for caution. AVEs were also greater than the correlation between the two dimensions, supporting discriminant validity.

Figure 2: Two-Factor Measurement Model

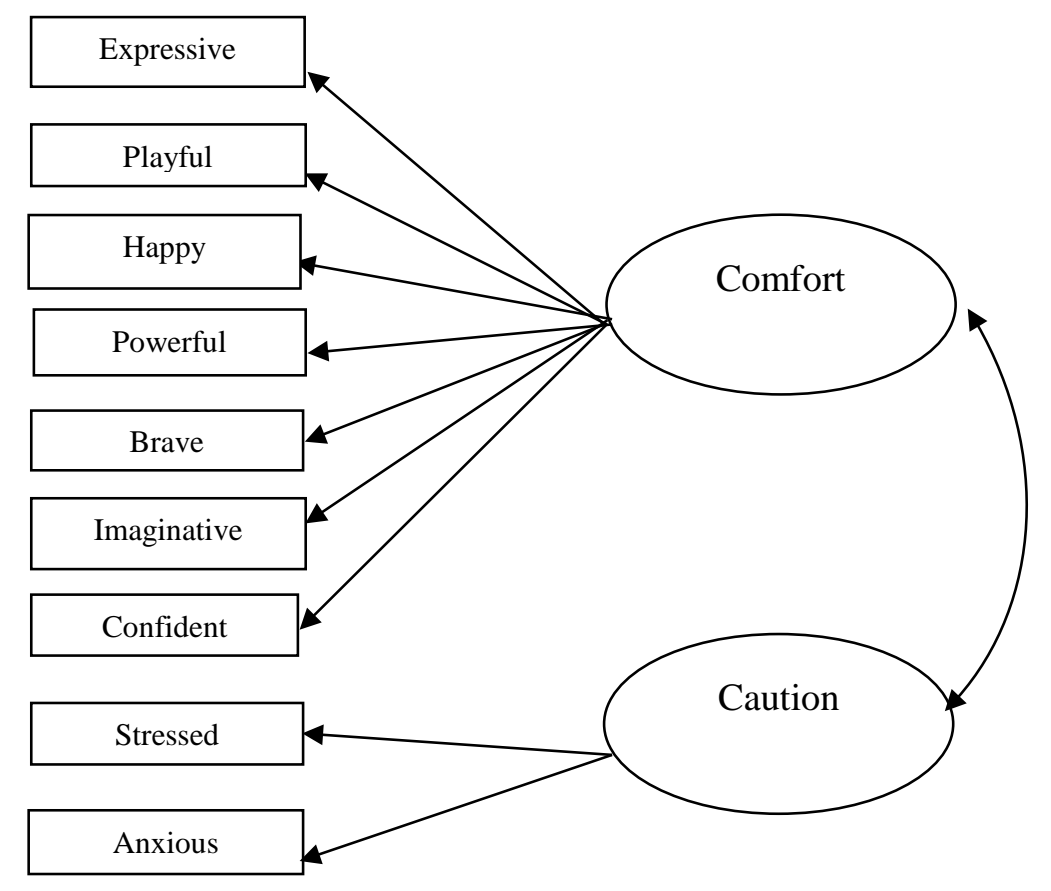


Internal consistency reliabilities were then gauged for all countries and all scales used (Table 2). Average alpha values were: 0.85 (comfort), 0.68 (caution) and 0.74 (online brand perceptions).

Table 2 here.

\section{Measurement Invariance}

Prior to examining the relationships among the constructs under investigation, cross-national invariance of the measures needed to be established. Measurement invariance is a prerequisite in order to compare relationships between constructs in different countries. In line with procedures outlined in the literature (Steenkamp and Baumgartner, 1998), an omnibus test was undertaken, where the strictest level of invariance necessary was imposed. More specifically, metric and factor variance invariance were tested simultaneously for the affective states and online brand perceptions scales. The model with the factor variance constraints produced poorer fit indices $\left(\chi^{2}(380)=806.643, \mathrm{p}<.01 ; \mathrm{CFI}=.90, \mathrm{TLI}=.90\right.$, RMSEA $=.03)$ compared with the unconstrained model $\left(\Delta \chi^{2}(52)=140.685, \mathrm{p}<.01\right)$. Although the fit indices were just at acceptable levels and did not reach the recommended .95 threshold (Hu and Bentler 1999), we proceeded with the analysis having imposed the strictest level of invariance needed (i.e. factor variance invariance). This was done in order to allow for reliable comparisons to be made with regards to the impact of comparative affective states on online brand perceptions across the five countries investigated. 


\section{Hypothesis Testing}

Following the measurement invariance restrictions, the structural model was tested and again acceptable levels of fit were obtained: $\chi^{2}(476)=931.954(\mathrm{p}<.01)$, CFI $=.90$, TLI $=.89$, RMSEA $=.03$. The second step involved testing the hypothesized relationships (see Table 3 for a summary of the results). The results indicate a significant effect of positive comparative affective states (i.e. comfort) on online brand perceptions across the five countries, confirming H1. Contrary to H1, H2 was rejected as findings fail to provide support for the impact of negative comparative affective states (i.e. caution) on online brand perceptions in all national contexts investigated.

Table 3 here.

To gain a better understanding of the non-significant impact of caution on online brand perceptions, we further tested for suppression effects that might exist between comfort and caution. More specifically, in order to investigate whether the impact of comfort is drowning out the impact of caution we used a chi-square test to compare the model where the covariances between comfort and caution were freely estimated with the model where the same covariances were constrained to be equal across countries. The chi-square test highlights that covariances vary across the five countries $\left(\Delta \chi^{2}(4)=9.537, \mathrm{p}<.05\right)$. An investigation of the correlations between comfort and caution, however, shows no significant relationships in any of the countries in our sample (Table 4). Following from the very small covariances and correlations, we can conclude that there are no suppression effects of comfort on caution.

Table 4 here. 
Following the hypotheses testing, the next step involved a comparison of the relationships across the five countries. Firstly, we imposed all regression weights to be equal across the five countries (fully restricted model). A chi-square comparison showed a significant deterioration when all paths were restricted to be equal compared with the baseline model $\left(\Delta \chi^{2}(8)=28.256, \mathrm{p}<0.01\right)$, providing support for the varying impact of positive comparative affective states across the five countries investigated. Secondly, each country was compared against the other four by constraining the relevant path from comfort to online brand perceptions. The results indicate significant differences for the US sample, suggesting that the impact of comfort on online brand perceptions is different only in the US and that online brand perceptions in the four remaining countries (UK, Australia, Canada and China) are similarly affected by comfort (Table 5). An examination of the regression weights indicates that the impact of comfort on online brand perceptions is stronger in the US than the remaining four countries $(b=0.58, t=6.232, p<.01$ in US and $b=0.38, t=8.246, p<.01$ in China, UK, Australia and Canada).

Table 5 here.

\section{DISCUSSION}

The findings show a significant direct effect of positive comparative affective states (i.e. comfort) on online brand perceptions across our five samples corroborating and augmenting existing evidence (e.g., Jones et al., 2008) that positive online affective states lead to more favorable brand perceptions. In this cross-national study, positive comparative affective states are found to influence consumers' perceptions of online brands across countries underlining the powerful role of affect in consumer decision making and providing support for the value 
of emotional branding particularly in an online context (Gobé, 2001; Thompson et al., 2006). Interestingly, support that negative comparative affective states may deteriorate consumers' perceptions of online brands is not found. This is contrary to our expectation and the literature on emotions (e.g., Menon and Kahn, 2002; Penz and Hogg, 2011), and it may be explained by the higher tolerance that people exhibit towards the online channel. Thus, caution experienced by consumers in an online context may not necessarily translate to negative perceptions towards online brands. Another explanation may be that negative affective states, such as stress and anxiety, may in fact be related to consumers' own limited experience with technology and/or the Internet. Such a realization that the "locus of blame" (Milstein, 1977) may indeed be internal prevents consumers from assigning responsibility to online brands, thus, leaving online brands intact.

Although the findings suggest that positive comparative affective states systematically (i.e. across our samples) influence consumers' perceptions of online brands, subsequent analysis shows that the magnitude of this effect does, indeed, vary by country. In particular, positive comparative affective states for our American sample are found to more strongly influence online brand perceptions compared to our samples from UK, Canada, Australia and China. Contrary to our expectations, China (the only Eastern country in our sample) is found to behave in similar ways with Western countries in regards to the impact of positive affective states on online brand perceptions. Previous research suggests that while individualist cultures (such as USA, UK, Australia and Canada) promote emotional expression, collectivist cultures such as China promote emotional moderation (Eid and Diener, 2001). According to Eid and Diener (2001, p.883), "in China there is a general attitude to consider emotions as dangerous, irrelevant or illness causing... the moderation or suppression of emotions is generally highly valued in China". However, while this may be true in the offline world this may not be the case in the online environment, which provides a space for the Chinese to 
more freely express their emotions without 'losing face' (Monkhouse et al., 2012). This finding is also in line with researchers arguing that the Internet has contributed to a 'global consumer culture' (Cleveland and Laroche, 2007) and that narrow cultural conceptions may nowadays be obsolete.

Evidently our USA data suggests a stronger impact of positive affective states on online brand perceptions compared to the other four countries studied. While the USA differs from China across a range of cultural dimensions including individualism/collectivism and power distance (Hofstede, 2001), it is similar to the UK, Australia and Canada on the same dimensions rendering a logical explanation for the differences between the USA and that cluster of countries difficult. A possible explanation relates to the fact that the USA is found in previous research to be the most extraverted nation (Lynn and Hampson, 1975), defined by Mooradian and Swan (2006) as "energetic, cheerful, and sociable (i.e., predisposed toward affect and preferring interpersonal interaction)”. With such high levels of extraversion, American consumers may be more likely to experience more intense positive affective states and have these more strongly determine their perceptions of online brands. Another explanation may pertain to the history of the Internet and state of development of online brands. Due to the fact that the Internet is deeply embedded in American culture, American consumers might feel relatively more comfortable in an online environment compared with their counterparts from the other four countries in the sample, which followed the lead of the US in terms of the growth of the Internet and e-commerce. In light of this, it is not surprising that all the online brands featuring in Interbrand's (2013) list of Top 100 brands originate from the US (e.g. Google, Amazon, eBay, Facebook). 


\section{CONCLUSIONS, IMPLICATIONS AND LIMITATIONS}

Our study investigates the role of online affective states in shaping online brand perceptions using a cross-national research design. The study contributes to the limited research on online affective states by developing and empirically testing a model outlining the effect of positive and negative comparative affective states on online brand perceptions. Our research differs from most previous research, which focuses primarily on isolated emotions, since investigates (comparative) affective states as a holistic concept and how those impact on online brand perceptions. Furthermore, our contribution includes the testing of the model through consumer data from five countries (i.e., UK, USA, Australia, Canada and China) highlighting cultural variations pertaining to the relationship of affective states and brand perceptions online, that are relevant to scholars interested in cross-national and cross cultural research.

Further, in addition to the theoretical implications of this research, our findings bear significant implications for managers. The results inter alia suggest that positive online affective states impact consumers' perceptions of online brands. This positive relationship is supported by consumer data from five countries. Unlike other elements of branding that need adapting based on national culture, emotional branding is a strategy that arguably works across national boarders for online brands. Managers are encouraged to direct their resources to generating feelings of comfort (playfulness, excitement, happiness for example) in the online space as these are likely to translate into more favorable online brand perceptions rather than towards supressing caution, as the latter does not directly impact online brand perceptions. Particularly in the USA, managers are encouraged to employ strategies to trigger positive online affective states, as these are likely to have the strongest impact on American consumers' perceptions of online brands. 
Finally, like any other research, this study is not free of limitations. Although the selection of countries served the purpose of the research, this selection was based on convenience. Further research should employ a more balanced cultural sample that includes a wider representation of Asian nations. Also, the focus of this study was on national culture hence we encourage future research to also examine the role of culture (at the individual level) by measuring various cultural dimensions and investigating their moderating effect on the relationship between affective states and brand perceptions (on and offline). Additionally, the focus of this research has been purely on online brands, although, with most brands now being hybrid it will be interesting to see how comparative affective states affect the perceptions of hybrid brands or even brands which are exclusively offered offline. Some of the countries in our sample are quite diverse in terms of ethnicities that exist in these countries (e.g., Australia and US), therefore future research may also seek to examine the impact of affective states on online brand perceptions across different ethnicities or subcultures within these countries. For example, it could be argued that the stronger impact of affective states in the US could be due to increased levels of extraversion among Hispanics in this country. A more detailed analysis of the population within a country could help researchers understand the differences observed within and between countries. Last but not least, our research has focussed on brand perceptions (cognition). Future research may examine the role of affective states in impacting actual or intended (consumer) behavior such as intention to buy, willingness to spend more or intention to revisit a website. 


\section{REFERENCES}

Aaker, D.A. (1991), Managing Brand Equity, San Francisco: Free Press.

Aaker, D.A. (1996), Building Strong Brands, New York: The Free Press

Alba, J., Lynch, J., Weitz, B., Janiszewski, C., Lutz, R., Sawyer, A. and Wood, S. (1997), "Interactive home shopping: consumer, retailer, and manufacturer incentives to participate in electronic marketplaces," The Journal of Marketing, pp. 38-53.

Ajzen, I. (2001), “Nature and operation of attitude”, Annual Review of Psychology, Vol. 52, pp. 27-58.

Albers-Miller, N. and Gelb, B. (1996), "Business advertising appeals as a mirror of cultural dimensions: A study of eleven countries”, Journal of Advertising, Vol. 25, No. 4, pp. 57-70.

Alversia, Y., Michaelidou, N. and Moraes, C. (2013) “Online Consumer Engagement Behaviour: The Consumer-Based Antecedents”, 2013 World Marketing Congress, 17-20 July, Monash University, Melbourne.

Bagozzi, R.P., Gopinath, M. and Nyer, P.U (1999), “The role of emotions in marketing”, Journal of the Academy of Marketing Science, Vol. 27, No. 2, pp. 184-206.

Bagozzi, R. P. and Yi, Y. (1988), “On the evaluation of structural equation models”, Journal of the Academy of Marketing Science, Vol. 16, No. 1, pp. 74-94.

Barnes, S.J., Bauer, H.H., Neumann, M.M. and Huber, F. (2007), “Segmenting cyberspace: A customer typology for the internet. European Journal of Marketing, Vol. 41 Nos. 1/2, pp. 7193.

Batra, R. and Ray, M.L. (1986), “Affective responses mediating acceptance of advertising”, Journal of Consumer Research, Vol. 13, No. 2, pp.234-248. 
Beedie, C., Terry, P. and Lane, A. (2005), "Distinctions between emotion and mood", Cognition \& Emotion, Vol. 19, No 6, pp. 847-878.

Cadogan, J. W., Lee, N., and Chamberlain, L. (2013). Formative variables are unreal variables: Why the formative MIMIC Model is invalid. Academy of Marketing Science Review, Vol. 3, No. 1, pp. 38-49

Celsi, R. L., Rose, R. L. and Leigh, T.W. (1993), “An exploration of high-risk leisure consumption through skydiving”, Journal of Consumer Research, Vol. 20, No. 1, pp. 1-23.

Christodoulides, G., de Chernatony, L., Furrer, O., Shiu, E. and Abimbola, T. (2006) “Conceptualising and measuring the equity of online brands" Journal of Marketing Management, Vol. 22, No. 7/8, pp. 799-825.

Christodoulides, G. (2009) “Branding in the post-internet era,” Marketing Theory, Vol. 9, No. 1, pp. 141-44.

Christodoulides, G., Jevons, C. and Bonhomme, J. (2012), “Memo to marketers: Quantitative evidence for change: How user-generated content really affects brands?” Journal of Advertising Research, Vol. 52, No. 1, pp. 53-64.

Christodoulides, G., Michaelidou, N. and Siamagka, N. T. (2013), “A Typology of internet users based on comparative affective states: Evidence from eight countries”, European Journal of Marketing, Vol. 47, No. 1/2, pp. 153-173.

Churchill Jr, G. A. (1979), “A paradigm for developing better measures of marketing constructs”, Journal of Marketing Research, Vol. 16, No. 1, pp. 64-73.

Clark, M. S., \& Isen, A. M. (1982). Toward understanding the relationship between feeling states and social behavior. In Hastorf, A.H. and Isen, A.M. (Eds.), Cognitive social psychology, pp.73-108 
Cleveland, M. and Laroche, M. (2007), “Acculturation to the global consumer culture: Scale development and research paradigm”, Journal of Business Research, Vol. 60, No. 3, pp. 249259.

Cohen, J. B. and Andrade, E. B. (2004), “Affective intuition and task-contingent affect regulation”, Journal of Consumer Research, Vol. 31, No. 2, pp. 358-367.

Cohen, J.B. and Areni C.S. (1991), “Affect and consumer behavior, in Handbook of Consumer Behavior, in Thomas S. Robertson and Harold H. Kassarjian (eds), NJ: Prentice Hall, pp. 188-240.

Danaher, P. J., Wilson, I. W., and. Davis, R. A. (2003), "A comparison of online and offline consumer brand loyalty," Marketing Science Vol. 22, No. 4 pp. 461-476.

Degeratu, A. M., Arvind Rangaswamy, A., and Jianan Wu, J. (2000), "Consumer choice behavior in online and traditional supermarkets: The effects of brand name, price, and other search attributes," International Journal of Research in Marketing, Vol. 17, No. 1 pp. 55-78.

De Mooij, M. (2013). “On the misuse and misinterpretation of dimensions of national culture, ” International Marketing Review, Vol. 30 No. 3, pp. 253-261.

De Mooij, M. and Hofstede, G. (2002), “Convergence and divergence in consumer behaviour: implication for international retailing”, Journal of Retailing, Vol. 78, pp. 61-69.

Dobele, A., Lindgreen, A., Beverland, M., Vanhamme, J. and van Wijk, R. (2007), “Why pass on viral messages? Because they connect emotionally”, Business Horizons, Vol. 50, No. 4, pp. 291-304.

Dobni, D., and George M. Zinkhan, G. M. (1990), "In search of brand image: a foundation analysis," Advances in consumer research, Vol. 17, No. 1, pp. 110-119. 
Eid, M., and Diener, E. (2001), “Norms for experiencing emotions in different cultures: Interand intranational differences”, Journal of Personality and Social Psychology, Vol.81, pp. 869-885.

Erdem, T., Swait, J. and Valenzuela, A. (2006), "Brands as signals: A cross-country validation study”, Journal of Marketing, Vol. 70, No. 1, pp. 34-49.

Frijda, N.H. (1993), “Moods, emotion episodes, and emotions”. In Handbook of Emotions, in Lewis, M and Haviland, J.M (Eds), New York: Guilford, pp. 381-403.

Fornell, C., and Larcker, D.F. (1981). Evaluating structural equation models with unobserved variables and measurement error. Journal of Marketing Research, No. 18, No.1, 39-50.

Foxall, G.R. (1997), “The emotional texture of consumer environments: A systematic approach to atmospherics”, Journal of Economic Psychology, Vol. 18, No. 5, pp. 505-523.

Gardner, B.B. and Levy, S.J. (1955), “The Product and the brand,” Harvard Business Review, Vol. 33 (March-April), pp. 33-39.

Gobé, M. (2001), Emotional Branding: The New Paradigm for Connecting Brands to People. New York: Allworth Press.

Henseler, J., Horváth, C., Sarstedt, M. and Zimmermann, L. (2010), “A cross-cultural comparison of brand extension success factors: A meta-study", Journal of Brand Management, Vol. 18, No. 1, pp. 5-20.

Ho, D. Y. and Chiu, C. (1994). Component ideas of individualism-collectivism, and social organization: An application in the study of Chinese culture. In U. Kim, H. C. Triandis, C. Kagitcibasi, S. Choi \& G. Yoon (Eds.), Individualism and collectivism: Theory, method, and applications (pp. 123-136). Thousand Oaks, CA: Sage. 
Hofstede, G. (1980), Culture's consequences: International differences in work-related values, Beverly Hills, CA: Sage Publications.

Hofstede, G. (2001), Culture's consequences: Comparing values, behaviors, institutions, and organizations across nations, Thousand Oaks, CA: Sage Publications

Hu, L. and Bentler, P.M. (1999), "Cutoff criteria for fit indexes in covariance structure analysis: Conventional criteria versus new alternatives", Structural Equation Modeling, Vol. 6, No. 1, pp. 1-55.

Interbrand, (2013) Best Global Brands 2013, available at http://www.interbrand.com (accessed 1 July 2013)

Jones, M.Y., Spence, M.T. and Vallaster, C. (2008), “Creating emotions via B2C websites” Business Horizons, Vol. 51, pp.419-428.

Keller, K. (1993), “Conceptualizing, measuring, and managing customer-based equity”, Journal of Marketing, Vol. 57 No. 1, pp. 1-22

Keller, K. L. (2003), Strategic Brand Management: Building, Measuring, and Managing Brand Equity, $2^{\text {nd }}$ Ed, NJ: Prentice Hall, Upper Saddle River.

Korgaonkar, P. K., and Wolin, L. D. (1999). A multivariate analysis of web usage. Journal of Advertising Research, 39, 53-68.

Kwon, W-S., and Lennon, S. J. (2009), "Reciprocal effects between multichannel retailers’ offline and online brand images," Journal of Retailing, Vol. 85, No. 3, pp. 376-390.

Kwortnik, R.J. and Ross, W.T. (2007), “The role of positive emotions in experiential decisions”, International Journal of Research in Marketing, Vol. 24, pp. 324-335. 
Lavine, H. Thomsen, C. J. and Borgita, E. (1999), “On the primary of affect in the determination of attitudes and behavior: The moderating role of affective-cognitive ambivalence”, Journal of Experimental Social Psychology, Vol. 34, pp.398-342.

Laros, F.J.M. and Steenkamp, J.B.E.M. (2005), "Emotions in consumer behavior: A hierarchical approach”, Journal of Business Research, Vol. 58, No. 10, pp. 1437-1445.

Lim, K.S., Lim, J.S. and Heinrichs, J.H. (2008), “Testing an integrated model of E-shopping website usage”, Journal of Internet Commerce, Vol. 7, No 3, pp. 291-312.

Low, G.S. and Lamb, C.W. (2000), “The measurement and dimensionality of brand associations”, Journal of Product \& Brand Management, Vol. 9 No. 6, pp. 350-68, Lynn, R. and Hampson, S. L. (1975), “National differences in extraversion and neuroticism”, British Journal of Social and Clinical Psychology, Vol. 14, pp. 223-240.

Mano, H. and Oliver, R. L. (1993), “Assessing the dimensionality and structure of the consumption experience: evaluation, feeling, and satisfaction”, Journal of Consumer research, pp. 451-466

Matsumoto, D. (1989), "Cultural influences on the perception of emotions”, Journal of Cross-Cultural psychology, Vol. 20, No. 1, pp. 92-105.

Matusitz, J. and Musambira, G. (2013), "Power distance, uncertainty avoidance, and technology: Analyzing Hofstede's dimensions and human development indicators”, Journal of Technology in Human Services, Vol. 31, pp. 42-60.

Menon, S. and Kahn, B. (2002), “Cross-category effects of induced arousal and pleasure on the internet shopping experience”, Journal of Retailing, Vol. 78 No.1, pp. 31-40. 
Milstein, J.S. (1977), "Attitudes, knowledge, and behavior of American consumers regarding energy conservation with some implications for governmental action", Advances in Consumer Research, Vol. 4, pp. 315-321.

Monkhouse, L.L., Bradley R.B., and Ute S. (2012), “The influence of face and group orientation on the perception of luxury goods: A four market study of East Asian consumers", International Marketing Review, Vol. 29, No. 6, pp.647-672.

Moon, J., Chadee’ M. and Tikoo, S. (2008), “Culture, product type, and price influences on consumer purchase intention to buy personalized products online”, Journal of Business Research, Vol. 61, No. 1, pp. 31-39.

Mooradian, A.T. and Swan, K.S. (2006), "Personality-and-culture: The case of national extraversion and word-of-mouth”, Journal of Business Research, Vol. 59, pp. 778-785.

Park, C. and Jun, J. (2003), “A cross-cultural Comparison of internet buying behavior: Effects of internet usage, perceived risks, and innovativeness', International Marketing Review, Vol. 20, No. 5, pp. 534-553.

Penz, E. and Hogg, M.K. (2011), "The role of mixed emotions in consumer behavior: Investigating ambivalence in consumers' experiences of approach-avoidance conflicts in online and offline settings”, European Journal of Marketing, Vol. 45, No. 1/2, pp. 104-132.

Pieters, R.G.M. and Van Raaij, W.F. (1988), "Functions and management of affect: Applications to economic behavior", Journal of Economic Psychology, Vol. 9, No. 2, pp. 251-282.

Ranaweera, C., Bansal. H. and McDougall G. (2008), "Web site satisfaction ad purchase intentions”, Managing Service Quality, Vol. 18, No. 4, pp. 329-348.

Richins, M.L. (1997), "Measuring emotions in the consumption experience”, Journal of Consumer Research, Vol. 24, No. 2, pp. 127-46. 
Robinson, C (1996), "Asian cultures: the marketing consequences", Journal of the Market Research Society, Vol. 38 No.1, pp.55-62.

Romaniuk, J. and Nicholls, E. (2006), “Evaluating advertising effects on brand perceptions: incorporating prior knowledge”, International Journal of Market Research, Vol. 48, No. 2, pp. 179-192.

Ruth, J.A., Brunel, F.F. and Otnes, C.C. (2002), “Linking Thoughts to Feelings: Investigating Cognitive Appraisals and Consumptions Emotions in a Mixed-Emotions Content”, Journal of the Academy of Marketing Science, Vol. 30, No. 1, pp. 44-58.

Scherer, K. R. (2005), “What are emotions? And how can they be measured?”, Social Science Information, Vol. 44, No. 4, pp. 695-729.

Schmitt, B. (2012), "The consumer psychology of brands." Journal of Consumer Psychology, Vol. 22, no. 1 pp. 7-17.

Shavitt, S., Lee, A. Y., \& Johnson, T. P. (2008). Cross-cultural consumer psychology. In C. Haugtvedt, P. Herr \& F. Kardes (Eds.), Handbook of consumer psychology (pp. 11031131). Mahwah, NJ: Erlbaum

Soares, A. M., Farhangmehr, M. and Shoham, A. (2007), “Hofstede's dimensions of culture in international marketing studies”, Journal of Business Research, Vol. 60, No. 3, pp. 277284.

Steenkamp, J. B. E. and Baumgartner, H. (1998), “Assessing measurement invariance in cross-national consumer research”, Journal of Consumer Research, Vol. 25, No. 1, pp. 78107.

Steenkamp, J. B. E., Hofstede, F. T. and Wedel, M. (1999), “A cross-national investigation into the individual and national cultural antecedents of consumer innovativeness”, Journal of Marketing, pp. 55-69. 
Tellegen, A., Watson, D. and Clark, L. A. (1999), “On the dimensional and hierarchical structure of affect”, Psychological Science, Vol. 10, No. 4, pp. 297-303.

Teo, T. (2001), "Demographic and motivation variables associated with Internet usage activities”, Internet Research: Electronic Networking Applications and Policy, Vol. 11, No. 2, pp. 125-37.

Thompson, C. J., Rindfleisch, A., and Arsel, Z. (2006), “Emotional branding and the strategic value of the Doppelgänger brand image”, Journal of Marketing, Vol. 70, pp.50-64.

Romaniuk, Jenni, and Magda Nenycz-Thiel. (2013) "Behavioral brand loyalty and consumer brand associations," Journal of Business Research Vol. 66, no. 1 67-72.

Van Everdingen, Y. M. and Waarts, E. (2003), “The effect of national culture on the adoption of innovations”, Marketing Letters, Vol. 14, No. 3, pp. 217-232

Vanhamme, J. and Lindgreen, A. (2001), “Gotcha! findings from an exploratory Investigation on the dangers of using deceptive practices in the mail-order business”, Psychology \& Marketing, Vol. 18, No. 7, pp.785-810.

Watson, D., Clark, L. A. and Tellegen, A. (1988), "Development and validation of brief measures of positive and negative affect: the PANAS scales”, Journal of Personality and Social Psychology, Vol. 54, No. 6, pp. 1063-1070.

Watson, D. and Tellegen, A. (1985), “Toward a consensual structure of mood”, Psychological Bulletin, Vol. 98, No. 2, pp. 219-235.

Westbrook, R. A. (1987), "Product/consumption-based affective responses and post purchase processes”, Journal of Marketing Research, 258-270.

Westbrook, R.A. and Oliver, R.L. (1991), “The Dimensionality of consumption emotion patterns and consumer satisfaction”, Journal of Consumer Research, Vol. 18 No. 1, pp.84-91 
Williams, P. and Aaker J.L. (2002), “Can mixed emotions peacefully coexists?”, Journal of Consumer Research, Vol. 28, pp. 636-649.

Yaveroglu, I. S. and Donthu, N. (2002), “Cultural influences on the diffusion of new products”, Journal of International Consumer Marketing, Vol. 14, No. 4, pp. 49-63.

Yeniyurt, S. and Townsend, J. D. (2003), “Does culture explain acceptance of new products in a country?: An empirical investigation”, International Marketing Review, Vol. 20, No. 4, pp. 377-396. 
Table 1: Demographic Profiles of the Sample

\begin{tabular}{lccccc}
\hline & UK & USA & Australia & Canada & China \\
\hline Gender & $\mathrm{N} /(\%)$ & $\mathrm{N} /(\%)$ & $\mathrm{N} /(\%)$ & $\mathrm{N} /(\%)$ & $\mathrm{N} /(\%)$ \\
$\quad$ Male & $100(50)$ & $100(49.5)$ & $98(47.1)$ & $96(48.7)$ & $127(63.2)$ \\
$\quad$ Female & $100(50)$ & $102(50.5)$ & $110(52)$. & $101(51.3)$ & $74(36.8$ \\
Age & & & & & \\
16-30 & $42(21)$ & $50(24.8)$ & $55(26.4)$ & $49(24.8)$ & $76(37.8)$ \\
$31-40$ & $50(25)$ & $48(23.8)$ & $39(18.7)$ & $48(24.3)$ & $48(23.8)$ \\
$41-50$ & $54(27)$ & $52(25.7)$ & $40(19.2)$ & $49(24.8)$ & $22(10.9)$ \\
$51+$ & $54(27)$ & $52(25.7)$ & $74(35.5)$ & $51(25.8)$ & $55(27.3)$ \\
Working status & & & & & \\
Unemployed & $30(15)$ & $62(30.6)$ & $54(25.9)$ & $49(24.8)$ & $24(11.9)$ \\
Retired & $60(30)$ & $38(18.8)$ & $44(21.1)$ & $47(23.8)$ & $45(22.3)$ \\
PT student & $7(3)$ & $3(1.5)$ & $3(1.4)$ & $3(1.5)$ & $8(3.9)$ \\
FT student & $15(7.5)$ & $21(10.3)$ & $10(4.8)$ & $14(7.1)$ & $18(8.9)$ \\
PT job & $19(9.5)$ & $12(5.9)$ & $31(14.9)$ & $19(9.6)$ & $12(5.9)$ \\
FT job & $50(25)$ & $50(24.7)$ & $48(23)$ & $50(25.3)$ & $89(44.2)$ \\
Other & $19(9.5)$ & $16(7.9)$ & $18(13.4)$ & $15(7.6)$ & $5(2.4)$ \\
Total & & & & & \\
& 200 & 202 & 208 & 197 & 201 \\
\hline
\end{tabular}


Table 2: Internal Consistency Reliabilities

\begin{tabular}{lccccc}
\hline & UK & US & AUS & CAN & CH \\
\hline Comfort & 0.88 & 0.89 & 0.87 & 0.88 & 0.73 \\
Caution & 0.70 & 0.62 & 0.73 & 0.65 & 0.72 \\
Online Brand Perceptions & 0.79 & 0.82 & 0.76 & 0.71 & 0.64 \\
& & & & & \\
\hline
\end{tabular}


Table 3: Model path coefficients and t-values (Dependent Variable: Online Brand Perceptions)

\begin{tabular}{|c|c|c|c|c|c|}
\hline \multicolumn{6}{|c|}{ Unstandardized Coefficients (t-values) } \\
\hline & UK & USA & Australia & Canada & China \\
\hline \multicolumn{6}{|c|}{ Independent Variables } \\
\hline Comfort & $0.470(4.840)^{* *}$ & $0.577(6.099) * *$ & $0.407(4.894)^{* *}$ & $0.340(3.865)^{* *}$ & $0.328(3.865)^{* *}$ \\
\hline Caution & $0.005(0.157)$ & $0.008(0.157)$ & $0.006(0.157)$ & $-0.007(-0.157)$ & $0.002(0.153)$ \\
\hline \multicolumn{6}{|c|}{ Control Variables } \\
\hline Age & $0.116(1.961)^{*}$ & $0.069(1.334)^{*}$ & $0.018(0.429)$ & $0.021(0.579)$ & $0.053(1.300)^{*}$ \\
\hline Gender & $-0.181(-1.399)$ & $0.120(1.1 .026)$ & $0.118(1.159)$ & $0.073(0.663)$ & $-0.100(-0.947)$ \\
\hline $\mathrm{R}^{2}$ & 0.170 & 0.236 & 0.198 & 0.134 & 0.165 \\
\hline
\end{tabular}


Table 4: Covariance/Correlation Matrix

\begin{tabular}{lcccccccccc}
\hline & \multicolumn{1}{c}{1} & \multicolumn{1}{c}{2} \\
\hline & UK & US & AUS & CAN & CH & UK & US & AUS & CAN & CH \\
\hline Comfort & & & & & & -.02 & $\mathbf{. 0 7}$ & $\mathbf{. 0 9}$ & .01 & -.06 \\
Caution & -.01 & .03 & .04 & .00 & -.02 & & & & &
\end{tabular}

$\begin{array}{llllllllllll}\text { Online Brand Perceptions } & .36 & & .47 & .44 & .36 & .32 & .02 & .05 & .04 & -.04 & .18\end{array}$

Notes: Correlations are in italics (correlations significant at .01 in bold); Covariances are in the first row (covariances significant at .05 in bold); 1=Comfort, 2=Caution 
Table 5: Comparison of Alternative Models

\begin{tabular}{lllllll}
\hline & $\chi^{2}(\mathbf{d f})$ & $\Delta \chi^{2}(\Delta \mathbf{d f})$ & CFI & TLI & NFI & RMSEA \\
\hline Baseline Model & $931.954(476)$ & & .90 & .89 & .81 & .03 \\
Fully Restricted & $960.210(484)$ & $28.256(8)$ & .89 & .88 & .81 & .03 \\
China $\neq$ USA, & $958.755(483)$ & $1.456(1)$ & .89 & .88 & .79 & .03 \\
$\begin{array}{l}\text { Australia, Canada, UK } \\
\text { UK } \neq \text { USA, Australia, }\end{array}$ & $959.920(483)$ & $0.291(1)$ & .89 & .88 & 81 & .03 \\
$\begin{array}{l}\text { Canada, China } \\
\text { USA } \neq \text { Australia, }\end{array}$ & $956.086(483)$ & $4.124(1)^{*}$ & .89 & .88 & 81 & .03 \\
$\begin{array}{l}\text { Canada, UK, China } \\
\text { Australia } \neq \text { Canada, }\end{array}$ & $960.186(483)$ & $0.025(1)$ & .89 & .88 & .81 & .03 \\
$\begin{array}{l}\text { China, UK, USA } \\
\text { Canada } \neq \text { UK, China }\end{array}$ & $959.046(483)$ & $1.165(1)$ & .89 & .88 & .81 & .03 \\
\begin{tabular}{l} 
Australia,Canada \\
\hline
\end{tabular} & & & & & & \\
\hline
\end{tabular}

$* \mathrm{p}<0.05$ 


\section{Appendix}

\section{Comfort*}

Expressive

Playful

Happy

Powerful

Brave

Imaginative

Confident

\section{Caution*}

Stressed

Anxious

\section{Online Brand Perceptions (7-Point Likert Scale)}

Online brands help me develop my identity and personality

Online brands are useful as they allow me to communicate with others

In one way or another, we all use online brands to help us define who we are

I can see how people might have different favourite online brands to suit their different online identities.

* The scale points for Comfort and Caution range from 1= Much more online than offline to $7=$ Much more offline than online 